\title{
Sabrina P. Ramet (ur.): Central and Southeast European Politics since 1989
}

\author{
Cambridge: Cambridge University Press, 2010, 563 strani
}

Urednica, avtorica uvoda in tudi soavtorica poglavja znanstvene monografije Central and Southeast European Politics since 1989, Sabrina P. Ramet, za slovensko bralstvo ne predstavlja novega imena, saj gre za plodno avtorico, katere raziskovalni fokus je področje nekdanje Jugoslavije ter t. i. nove Evrope. Kljub temu, da v slovenski jezik do sedaj ni bilo prevedeno niti eno samo delo, pod katerega bi se dr. Ramet podpisala kot avtorica oziroma urednica, je njena znanstvena misel poznana predvsem tistim, ki želijo skozi njeno raziskovalno delo spoznati zgodovino in družbene procese skozi prizmo interdisciplinarnega ter večkrat tudi eklektičnega pristopa.

Monografija Central and Southeast European Politics since 1989 se osredotoča na prikaz zgodovine političnih, ekonomskih ter diskurzivnih sprememb, ki so zaznamovale evropski prostor po padcu železne zavese. $\mathrm{V}$ delu, ki ga je s svojimi prispevki oblikovalo več kot dvajset raziskovalcev in raziskovalk, se tako bralec seznani s konfuznostjo konca osemdesetih let, prekinitvijo znane paradigme bipolarne delitve sveta ter razkritjem političnega dogajanja znotraj različnih držav, ki so »stari«, tj. zahodni Evropi pomenile nov politični in s tem tudi ekonomski izziv.

Problem, ki ga monografija izpostavlja že s svojim naslovom, je geografska umestitev in diskurzivni opis "novih" držav, ki so se po padcu železne zavese in razpadu držav federalnih tipov pojavile na zemljevidu Evrope kot samostojni politični akterji. Spremembe v (samo)prezentiranju držav, ki so bile še nedavno pojmovane kot del Vzhodne, tj. »druge« ter drugorazredne Evrope, so v devetdesetih letih preteklega stoletja spremenile svojo geografsko pozicijo s premikom v »napredno", Srednjo Evropo. Pri tem sta imela veliko vlogo tudi zgodovinska dediščina in spomin, ki sta prostor povezovala z miselnimi percepcijami Zahodne Evrope. Dvojnost, tako pristopa kot odnosa do novih samostojnih nosilcev lastnega partikularnega interesa, je s tem pridobila na pomenu in se še vedno izraža $v \mathrm{t}$. i. demokratizacijskih, evropeizacijskih ter integracijskih procesih vključevanja v nadnacionalne oblike sodelovanja.

Monografija je zaradi obravnave kompleksnosti pojavov znotraj prostora "novih" držav razdeljena na sedem delov, $s$ čimer skuša s primerno tematsko delitvijo 
vzpostaviti primeren in primerljiv kontekst. Zaradi (pomena) politične konotacije dogajanja od konca osemdesetih let dalje se tako vsa poglavja monografije usmerjajo $\mathrm{v}$ analizo (iz)gradnje sistema, politike in vladanja, vloge medijev, ekonomskih izzivov, kriminala, korupcije in odnosa do polpretekle zgodovine.

Znotraj uvodnega dela so tako izpostavljeni širši okviri, znotraj katerih so se znašle analizirane države, tj. tranzicijski okviri politične in ekonomske transformacije s privatizacijskimi shemami in preoblikovanjem socialistične državno-plansko vodene ekonomije v kapitalistični svobodni trg. Razumevanje lajtmotiva konca osemdesetih ter začetka devetdesetih, ki v določenih pogledih še zdaleč ni končan oziroma se njegova transformacija prilagaja trenutnim političnim in ekonomskim zahtevam zeitgeista, je tako predpogoj razumevanja političnih sprememb omenjenega obdobja.

Kljub temu novih samostojnih akterjev $\mathrm{v}$ areni mednarodne politike ne gre misliti kot pojav novih narodov, na kar opozori drugo poglavje uvodnega dela monografije. $S$ pojavom novih držav je prišlo do zadnje etape pri izoblikovanju držav (angl. nationbuilding), tj. političnega longue durée. Države, ki so znotraj evropskega prostora nastale po spremembah leta 1989, so bile tako »talke« prepletanja nacionalizma in socialističnega internacionalizma. Specifična zgodovinska dediščina, katere neposredna posledica je bil deficit demokratičnega principa vladavine zakona, je zaznamovala politični in ekonomski odnos ter diskurzivne prakse, ki jih je »stara« Evropa uporabljala v zvezi z novonastalimi državami.

Te so bile takoj na začetku samostojnosti podvržene reformam volilnih sistemov, s pomočjo katerih naj bi odpravile deficit demokratičnega principa vladavine prava iz njihove socialistične/komunistične preteklosti. Odnos vladajočega in vladanega se tako odraža tudi skozi prizmo ocenjevanja primernosti vzpostavljenih političnih sistemov in političnega režima znotraj držav. Ocenjevanje procesa demokratizacije ter posledično stopnje demokracije je bilo zaradi strateških interesov tedanje Evropske skupnosti enostavnejše na področju držav, katerih pot v samostojnost je bila zaznamovana $\mathrm{z}$ vojaškimi obračuni.

Četrto poglavje knjige odpira vprašanje ekonomskih reform in iluzije tranzicije. Kot $\mathrm{v}$ predhodnem delu monografije je tudi $\mathrm{v}$ tem poglavju poudarjen odnos hegemonije $\mathrm{v}$ ekonomskem aspektu. Navidezna slika dobrih namenov in želje po vzpostavljanju stabilnih in pravičnih režimov, ki naj bi si jih ljudje po dolgotrajni socialistični in komunistični tiraniji zaslužili, je prikazana skozi prizmo neposrednih vplivov direktnih tujih investicij, ekonomskih intervencij ter vzpostavljanja novih trgov. Poglavje izpostavi razlike med različnimi oblikami ekonomske razvitosti, različnimi ekonomskimi politikami novih držav in njihovimi posledicami. 
Osrednji del monografije je namenjen analizi političnega dogajanja po posameznih državah znotraj treh sklopov, in sicer $\mathrm{z}$ analizo srednjeevropskih in baltskih držav ter držav jugovzhodne Evrope. Avtorji tako prikažejo zgodovino političnega dogajanja po letu 1989, ki ga z umestitvijo v historični kontekst ter kritično analizo razvoja dogodkov predstavijo v zgoščeni obliki. V svojih prikazih ne nizajo zgolj faktografskih podatkov, temveč jih postavljajo $\mathrm{v}$ kontekst ciljno usmerjenih politik znotraj spreminjajoče se podobe sveta po padcu berlinskega zidu. Analiza omenjenega početja bralcu služi kot sistematičen prikaz politične situacije znotraj transformaciji podvrženega območja.

Zaključek monografije s tremi poglavji analizira vprašanje varnosti, regionalnega sodelovanja, vprašanja demokratizacije $\mathrm{v}$ odnosu do Evropske unije ter soočanja $\mathrm{z}$ izzivi 21. stoletja. Avtorji v teh poglavjih izpostavijo vprašanje, v kateri smeri in na kakšen način bi se razvijale države, nastale na pogorišču hladne vojne, brez pritiska zunanjih nadnacionalnih formacij s politično, ekonomsko in militarno konotacijo. $S$ tem načenjajo vprašanje, ali so oblike integracijskih procesov predstavljale edini oziroma zadosten razlog za transformacijo novih držav v za zahodno ekonomijo sprejemljivo urejeno platformo oziroma ali lahko $\mathrm{v}$ primeru teh držav govorimo o pomanjkanju lastnih sposobnosti in ambicij za samorealizacijo.

Kljub poplavi naslovov del, ki v zadnjem desetletju odpirajo debato o vplivu Evropske unije oziroma drugih nadnacionalnih organizacij na novopridružene članice ter kandidatke za vstop v Evropsko unijo, je dodana vrednost monografije sinteza političnega razvoja po posameznih državah, ki jim je skupna zgodba o tranziciji, in kritična umestitev omenjenega prikaza glede na kontekst, znotraj katerega se (je) politični razvoj odvija(l). Kar znanstvena monografija zgolj površno omeni, je historična povezanost obstoječih družbenih, ekonomskih in političnih konstelacij s (pol)preteklo zgodovino oziroma vpetost $\mathrm{v}$ prostor, ki je svojo dokončno distinktivno in izključujočo podobo pridobil $\mathrm{v}$ dvajsetem stoletju. Ne gre namreč zanemariti zgodovinske zakoreninjenosti medsebojne odvisnosti, ki odpira tudi vprašanje, ali je do postberlinske tranzicije glede na ekonomsko izkoriščanje periferne podobe Evrope sploh kdaj prišlo. Prav tako pričujoče delo ne načenja vprašanja novih načinov ter dvosmernih diskurzivnih praks približevanja nadnacionalnim organizacijam, torej vprašanja spremembe odnosa iz recipročnosti $\mathrm{v}$ ambivalentnost. Kljub temu monografija prinaša analitičen in sistematičen pregled držav, ki so se na zemljevid mednarodne politike kot samostojni politični subjekti zavihtele šele pred dobrimi dvajsetimi leti, in je kot tak nepogrešljiv v knjižni zbirki vsakogar, ki se bolj poglobljeno ukvarja s podobo evropskega prostora po letu 1989. 